\author{
ALEKSANDRA KARCZEMNA ${ }^{1}$, JAROSŁAW KRZYWAŃSKI ${ }^{2}$, EWA LANGE ${ }^{1}$ \\ ${ }^{1}$ Katedra Dietetyki \\ Wydział Nauk o Żywieniu Człowieka i Konsumpcji \\ Szkoła Główna Gospodarstwa Wiejskiego w Warszawie \\ Nowoursynowska 159C, 02-776 Warszawa \\ ${ }^{2}$ Centralny Ośrodek Medycyny Sportowej \\ Centrum Medycyny Klinicznej i Doświadczalnej \\ Żwirki i Wigury 63A, 02-091 Warszawa \\ E-mail: aleksandra.karczemna@gmail.com
}

\title{
ZNACZENIE FOLIANÓW DLA OSÓB UPRAWIAJĄCYCH SPORT
}

\begin{abstract}
WSTEP
Odpowiednie żywienie, podobnie jak czynniki genetyczne, zdolności, siła, rodzaj treningu oraz typ uprawianego sportu, stanowi znaczacy czynnik wpływający na zdolność wysiłkowa sportowca. Sposób żywienia często określany jest także mianem „niewidzialnego treningu (ang. invisible training) (MARTINEZ i współaut. 2011). Sportowcy wyczynowi i amatorzy podejmujący rywalizację w zawodach wymagaja znacznie szerszej wiedzy oraz odpowiednich praktyk żywieniowych niż osoby uprawiające sport rekreacyjnie czy zdrowotnie (ESKICI i ERSOY 2012). Niepożądany wpływ ograniczonego spożycia białka, tłuszczu czy węglowodanów na sprawność fizyczna sa dobrze udokumentowane w literaturze. Odzwierciedlaja to rekomendacje towarzystw naukowych zajmujących się żywieniem sportowców, które precyzyjnie wskazuja normy spożycia tych składników dla sportowców (THOMAS i współaut. 2016). Odwrotna sytuacja ma miejsce $\mathrm{w}$ przypadku niedoboru $\mathrm{w}$ diecie witamin i składników mineralnych, dla których nie ustalono jak dotad zapotrzebowania dla sportowców i stosuje się wartości RDA (ang. recommended dietary allowance; zalecany dzienny poziom spożycia) dla populacji ogólnej. Nie jest dobrze poznany ich wpływ na wydolność i sprawność wysiłkowa człowieka (LUKASKI 2004). W zaleceniach wymienia się jedynie zwiększone zapotrzebowanie sportow-
\end{abstract}

ców na żelazo i wapń (MAUGHAN i współaut. 2018).

Istnieja dwie przyczyny występowania niedoborów u osób aktywnych fizycznie. Jedna $z$ nich dotyczy braku rekomendacji dotyczacych witamin i składników mineralnych dla osób o większym wysiłku fizycznym (i tym samym większym zapotrzebowaniu) niż na poziomie umiarkowanym, czyli przedstawionym w normach dla ludności polskiej. Brak tych zaleceń może doprowadzić do zaplanowania nieprawidłowego planu żywieniowego i tym samym nieadekwatnej podaży witamin i składników mineralnych, co następnie może skutkować niższym standardem treningu oraz uzyskaniem słabszych wyników sportowych. $Z$ kolei druga związana jest $z$ nadmierna utrata składników mineralnych i witamin $z$ powodu zwiększonego katabolizmu i wydalania (LUKASKI 2004, JAROSZ 2017).

Regularny, intensywny wysiłek fizyczny może wpływać na zmianę zapotrzebowania na niektóre witaminy i składniki mineralne poprzez kilka mechanizmów. Pierwszy $z$ nich dotyczy szlaków metabolicznych zwiazanych $\mathrm{z}$ produkcja energii $\mathrm{w}$ czasie wysiłku fizycznego, które ulegaja zaburzeniom na skutek działania stresora, w zwiąku z czym zapotrzebowanie na niektóre składniki odżywcze może wzrosnać. Drugi mechanizm związany jest $z$ adaptacjami biochemicznymi do wysiłku zachodzącymi w komórkach, co może zwiększać obrót i utratę określonego pier- 
wiastka, np. $z$ potem. Natomiast ostatni $z$ nich odnosi się do zwiększenia zapotrzebowania na skutek powysiłkowej regeneracji tkanek i konieczności utrzymania większej ilości beztłuszczowej masy ciała (RoussEAU i współaut. 2005, WOOLF i MANORE 2006). Podaż mikroskładników musi odpowiadać zapotrzebowaniu organizmu sportowca. Niewielkie ich niedobory $\mathrm{w}$ diecie moga istotnie oddziaływać na zdolność do wysiłku (LUKASKI 2004, LAZOVIĆ i współaut. 2018). Foliany stanowia grupę witamin, o nie do końca poznanej roli zwiąanej $z$ wysiłkiem fizycznym.

\section{FOLIANY I KWAS FOLIOWY - BUDOWA I FUNKCJE FIZJOLOGICZNE}

Odkrycie folianów (witamina $\mathrm{B}_{9}$ ) przypada na przełom lat 30. i 40. XX w., kiedy zostały wyekstrahowane $z$ wyciagu $z$ drożdży, a następnie wyizolowane $z$ liści szpinaku (CIEŚlIK i KoŚCIEJ 2011). Natomiast kwas foliowy (kwas pteroiloglutaminowy) zsyntetyzowano kilka lat później w laboratorium. Zbudowany jest on $\mathrm{z}$ kwasu $\mathrm{p}$-aminobenzoesowego (PABA), zasady pterydynowej (6-metylopteryny) i kwasu glutaminowego (Ryc. 1). Sam kwas foliowy bardzo rzadko występuje $\mathrm{w}$ naturze. Jest to postać syntetyczna, stanowiąca najbardziej utleniona formę kwasu (mono-)pteroiloglutaminowego, szeroko spotykana $\mathrm{w}$ różnego rodzaju preparatach farmaceutycznych, suplementach diety czy używana do wzbogacenia produktów spożywczych (np. mąk i produktów zbożowych w Stanach Zjednoczonych).

Natomiast zredukowane pochodne kwasu foliowego tworza grupe o nazwie foliany, powszechnie występująca w żywności. Dotychczas poznano ponad 150 zwiąków należacych do tej grupy. Foliany różnia się między soba przede wszystkim liczba reszt kwasu glutaminowego, rodzajem jednowęglowych podstawników, stopniem utlenienia pterydyny oraz biodostepnościa. Spośród wszystkich komponentów tej grupy, kwas foliowy cechuje się największą stabilnością (CZE-<smiles>Nc1nc2ncc(CNc3ccc(C(=O)NC(CCC(=O)O)C(=O)O)cc3)nc2c(=O)[nH]1</smiles>

Ryc. 1. Wzór strukturalny kwasu foliowego.

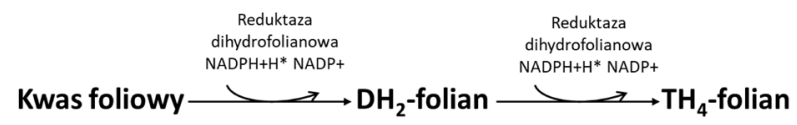

Ryc. 2. Redukcja kwasu foliowego do tetrahydrofolianu (CZECZOT 2008).

CZOT 2008, CIEŚlIK i KoŚCIEJ 2011, LASKOWSKA-KLITA i współaut. 2012, SIKORSKA-ZIMNY 2013).

Najbardziej aktywna biologicznie forma folianów jest tzw. tetrahyrofolian $(5,6,7,8$-tetrahydrofolian; $\mathrm{TH}_{4}$-folian). Powstaje on $\mathrm{w}$ procesie dwuetapowej redukcji (Ryc. 2) przez działanie reduktazy dehydrofolianowej (DHFR) i przy udziale $\mathrm{NADPH}+\mathrm{H}^{+}$. Dopiero w takiej formie może uczestniczyć w „cyklu folianowym". Reakcja ta zachodzi w watrobie (CzEczot 2008, SMith i współaut. 2008).

$\mathrm{TH}_{4}$-folian bierze udział w wielu biochemicznych reakcjach organizmu. Główna jego funkcja w komórkach polega na przenoszeniu grup jednowęglowych o różnym stopniu utlenienia (metylowej, metylenowej, metenylowej, formylowej oraz formiminowej), co pozwala na uczestniczenie w szeregu różnorodnych mechanizmów enzymatycznych. Jako koenzym uczestniczy w metabolizmie niektórych aminokwasów (seryny, glicyny, histydyny), a także w biosyntezie zasad purynowych (szczególnie de novo) i pirymidynowych (głównie tymidyny), będacych prekursorami DNA i RNA. Kwas foliowy odgrywa znaczaca rolę także w modyfikacjach epigenetycznych, czyli metylacji nici DNA i białek histonowych. Stanowi koenzym w procesie syntezy metioniny, będącej substratem do syntezy S-adenozylometioniny (SAM), która $z$ kolei pełni rolę donora grup metylowych podczas metylacji DNA (KALEMBA-DROŻDŻ 2011, WoOLF i współaut. 2017). Tetrahydrofolian jest niezbędny do różnicowania się komórek oraz stanowi kofaktor podczas powstawania erytrocytów (WoOLF i współaut. 2017). Dodatkowa funkcją folianów zawartych w komórkach, jako regulatorów, jest wywieranie allosterycznego wpływu na kilka enzymów bioracych udział w cyklu foliany-metionina, takich jak reduktaza metylenotetrahydrofolianowa (MTHFR), glicyno-N-metylotransferaza czy hydroksymetylotransferaza seryny. Niestety dokładny mechanizm tego zjawiska nie został do końca poznany (SMITH i współaut. 2008). Natomiast sama pterydyna (jako tetrahydrobiopteryna, $\mathrm{BH}_{4}$ ) uczestniczy w syntezie neuroprzekaźników katecholaminowych: dopaminy, adrenaliny i serotoniny (CZYŻEWSKA-MAJCHRZAK i PARADOWSKA 2010). Witamina $B_{9}$ wraz $z$ witamina $B_{12}$ stanowia niezbędne składowe $\mathrm{w}$ procesie remetylacji homocysteiny do metioniny. W przypad- 
Tabela 1. Zawartość folianów w produktach spożywczych (CzECzOT 2008, KunACHOwICZ i współaut. 2017).

\begin{tabular}{|c|c|c|}
\hline & Produkt & $\begin{array}{c}\text { Zawartość folianów } \\
(\mu \mathrm{g} / 100 \mathrm{~g})\end{array}$ \\
\hline \multirow{7}{*}{ Ciemnozielone warzywa liściaste } & Szpinak & 193 \\
\hline & Kapusta włoska & 80 \\
\hline & Brokuły & 119 \\
\hline & Brukselka & 130 \\
\hline & Szparagi & 150 \\
\hline & Sałata & 75 \\
\hline & Jarmuż & 120 \\
\hline \multirow{5}{*}{ Nasiona roślin strączkowych } & Fasola biała (nasiona suche) & 187 \\
\hline & Soja (nasiona suche) & 280 \\
\hline & Bób(nasiona suche) & 145 \\
\hline & Groszek zielony & 62 \\
\hline & Groch (nasiona suche) & 151 \\
\hline \multirow{6}{*}{$\begin{array}{l}\text { Warzywa i owoce zawierające duże ilości } \\
\text { witaminy C czy } \beta \text {-karotenu }\end{array}$} & Papryka czerwona & 52 \\
\hline & Pomarańcze & 30 \\
\hline & Maliny & 30 \\
\hline & Pietruszka (korzeń) & 180 \\
\hline & Pietruszka (liście) & 170 \\
\hline & Marchew & 32 \\
\hline \multirow{12}{*}{ Mąki i produkty zbożowe } & Otręby pszenne & 260 \\
\hline & Mąa pszenna (typ 500) & 54 \\
\hline & Mąa pszenna (typ 1850) & 109 \\
\hline & Makka żytnia (typ 580) & 23 \\
\hline & Maka żytnia (typ 200) & 82 \\
\hline & Ryż (niegotowany, różne rodzaje) & $29-53$ \\
\hline & Kasze (niegotowane) & $19-30$ \\
\hline & Chleb pełnoziarnisty $z$ żyta & 44,8 \\
\hline & Chleb pszenny & 30,7 \\
\hline & Bułki pszenne & 28,4 \\
\hline & Orzechy włoskie & 66 \\
\hline & Orzechy arachidowe & 110 \\
\hline Drożdże & Drożdże piekarskie (prasowane) & 1407 \\
\hline \multirow{5}{*}{ Mleko i produkty mleczne } & Mleko krowie & 5 \\
\hline & Fermentowane napoje mleczne & $7-10$ \\
\hline & Sery dojrzewajace twarde & $10-40$ \\
\hline & Sery dojrzewające miękkie & $60-100$ \\
\hline & Ser twarogowy & 27 \\
\hline \multirow{8}{*}{ Mięso, podroby, jaja i ryby } & Wątroba wołowa & 330 \\
\hline & Mięso (różne gatunki) & $3-10$ \\
\hline & Jaja kurze (całe) & 65 \\
\hline & Jaja kurze (żółtko) & 152 \\
\hline & Jaja kurze (białko) & 20 \\
\hline & Ryby (ogółem) & $5-12$ \\
\hline & Łosoś (świeży) & 26 \\
\hline & Tuńczyk (świeży) & 15 \\
\hline
\end{tabular}




\begin{tabular}{llr}
\hline & \multicolumn{1}{l}{$\begin{array}{l}\text { Karmelki nadziewane } z \text { witaminami (i bez } \\
\text { nich) }\end{array}$} & 800 (0) \\
\cline { 2 - 3 } & Płatki śniadaniowe & $179-185$ \\
\cline { 2 - 3 } Produkty wzbogacane (rynek polski) & $\begin{array}{l}\text { Płatki kukurydziane } \\
\text { (i bez wzbogacania) }\end{array}$ & 192 \\
\cline { 2 - 3 } & $\begin{array}{l}\text { Sok jabłkowy z witaminami } \\
\text { (i bez nich) }\end{array}$ & 43 (3) \\
\cline { 2 - 3 } & Sok grejpfrutowy z witaminami (i bez nich) & (6) \\
\cline { 2 - 3 } & Żelki „Vibovit” & 100 \\
\hline
\end{tabular}

ku niedoboru tych zwiazków oraz zaburzeń metabolicznych dochodzi do gromadzenia się homocysteiny we krwi, a następnie do wystapienia hiperhomocysteinemii. Nadmiar tego aminokwasu, przy niedoborze powyższych witamin, ma działanie prooksydacyjne i prozakrzepowe (stymuluje proces koagulacji), osłabia przyczepienie łożyska podczas ciąży, zwiększa ryzyko wystapienia udaru mózgu. Odpowiednia podaż kwasu foliowego zwiększa stężenie dostępnych grup metylowych, co pozytywnie stymuluje proces remetylacji homocysteiny, a w rezultacie zmniejsza jej koncentrację w komórkach i osoczu (CZECZOT 2008, GUJSKA i współaut. 2013, VIJAYAKUMAR i współaut. 2017).

\section{ŹRÓDŁA FOLIANÓW W ŻYWNOŚCI}

Foliany występuja zarówno w produktach pochodzenia roślinnego, jak i zwierzęcego, jednak ze względu na brak możliwości syntezy kwasu p-aminobenzoesowego oraz tworzenia połaczeń reszty pteroilowej $z$ glutaminianem $\mathrm{u}$ zwierzat, te pierwsze stanowia znacznie bogatsze źródło. Dlatego też główne źródło folianów dla człowieka stanowi dieta (CZECZOT 2008).

Najwięcej folianów znajduje się w ciemnozielonych warzywach liściastych (szczególnie w szpinaku, sałacie, kapuście, brokułach, brukselce, szparagach) oraz $\mathrm{w}$ pełnoziarnistych produktach zbożowych. Cennym źródłem sa także warzywa i owoce zawierające duże ilości witaminy $\mathrm{C}$ czy $\beta$-karotenu (papryka, cytrusy, maliny) oraz nasiona roślin strączkowych (bób, groszek zielony, groch, fasola), drożdże, orzechy. Wśród produktów pochodzenia zwierzęcego wysoka zawartościa folianów odznaczaja się podroby (szczególnie wątroba), jaja (głównie żółtko) i ryby (łosoś). Ze względu na obecność bakterii kwasu mlekowego niewielkie ilości tego zwiazku można znaleźć w fermentowanych produktach mlecznych, serach dojrzewajacych czy twarogu (Tabela 1). Dzięki obecności bakterii jelitowych $\mathrm{w}$ przewodzie pokarmowym człowieka także powstają znikome ilości witaminy $B_{9}$ (CIEŚLIK i KoŚcIEJ 2011,
MAHMOOD 2014 ). Niestety długi proces przetwórczy (obieranie, rozdrabnianie, mycie, obróbka termiczna), niekorzystne warunki środowiskowe oraz przechowywania produktów (obecność tlenu, ciepło, promienie słoneczne, kwasowość środowiska, jony metali ciężkich (np. żelazo) negatywnie wpływaja na zawartość folianów w produktach żywnościowych (CIEŚlIK i KośCIEJ 2011, THALER 2014). Ich straty często sięgaja rzędu 50-80\% (LASKOWSKA-KLITA i współaut. 2012).

\section{BIODOSTEPNOŚĆ FOLIANÓW}

Wchłanianie $z$ przewodu pokarmowego człowieka naturalnie występujacych folianów jest niższe niż syntetycznego kwasu foliowego (Winkels i współaut. 2007). Przyjmuje się, że bioprzyswajalność kwasu foliowego (spożytego na pusty żołądek) wynosi $100 \%$, naturalnie występujacych folianów ok. 50\%, natomiast kwasu foliowego $\mathrm{z}$ suplementów i fortyfikowanej żywności ok. 85\% (WINKELS i współaut. 2007, CZECZOT 2008, CIEŚlIK i KoŚCIEJ 2011, EFSA 2014, THALER 2014). Na biodostępność tych zwiazków ma wpływ wiele czynników, zarówno środowiskowych, jak i wewnatrzustrojowych (zwiazanych przede wszystkim $z$ funkcjonowaniem przewodu pokarmowego) (CZECZOT 2008).

$\mathrm{W}$ proksymalnym odcinku jelita cienkiego foliany pobrane $z$ pożywieniem (forma poliglutaminowa) ulegaja rozkładowi przez swoiste dekoniugazy (szczególnie karboksypeptydaze folilopoliglutaminowa, GCP2) do pochodnych monoglutaminowych. Nastepnie związki te w komórkach błony śluzowej jelita ulegaja rozkładowi do 7,8-dihydrofolianu $\left(\mathrm{DH}_{2}\right.$-folianu) oraz najbardziej aktywnej biologicznie postaci 5,6,7,8-tetrahydrofolianu $\left(\mathrm{TH}_{4}\right.$-folian). W takiej postaci sa transportowane $z$ krwia do tkanek. Tam przy udziale przenośnika, białka błonowego (w przypadku form zredukowanych), lub receptora błonowego (formy zredukowane i utlenione) na drodze endocytozy (tzw. potocytozy) transportowane są do wnętrza komórek, gdzie ponownie przybieraja (ujemnie naładowana) formę poliglutaminowa dzięki działaniu syn- 
tetazy folipoli-y-glutaminowej oraz obecności zwiazku wysokoenergetycznego ATP. Taka postać uniemożliwia przedostanie się koniugatów przez błonę komórki na zewnątrz i pozwala na tworzenie zapasów folianów w narządach (szczególnie w wątrobie) (CZECZOT 2008, LASKOWSKA-KLITA i współaut. 2012).

Największe stężenie folianów we krwi można zaobserwować już po 30-60 min od spożycia posiłku, natomiast ich okres półtrwania w osoczu wynosi od 3 do 3,5 godziny (CZECZOT 2008). Wydalenie folianów $z$ organizmu człowieka następuje $z$ moczem. W związu $z$ produkcja folianów przez bakterie mikroflory jelitowej człowieka oraz utrata związaną $z$ kwasami żółciowymi i komórkami jelit, w zależności od perystaltyki i charakterystyki mas kałowych foliany wydalane sa także $z$ kałem. Przyjmuje się, iż dobowa utrata tego zwiazku $z$ wydalinami wynosi ok $240 \mu \mathrm{g}$. Część folianów dostarczonych z dieta zużywaja bakterie jelitowe (WINKELS i współaut. 2007, CZECZOT 2008, CZYŻEWSKA-MAJCHRZAK i PARADOWSKA 2010).

\section{ZAPOTRZEBOWANIE ORGANIZMU NA FOLIANY - NORMY}

Ze względu na występujące różnice w poziomie biodostępności folianów pochodzących $z$ różnych źródeł oraz syntetycznego kwasu foliowego wprowadzono dietetyczne ekwiwalenty kwasu foliowego (ang. dietary folate equivalents, DFE), przyjmujac: 1 $\mu \mathrm{g}$ DFE $=1 \mu \mathrm{g}$ folianów $\mathrm{z}$ pożywienia $=0,6$ $\mu \mathrm{g}$ kwasu foliowego $z$ żywności wzbogacanej oraz $z$ suplementów diety (spożytych wraz $Z$ żywnościa) $=0,5 \mu \mathrm{g}$ kwasu foliowego $\mathrm{z}$ suplementu diety spożytego na czczo (EFSA 2014). Zgodnie $z$ aktualnymi normami (JAROSZ 2017) zalecane dzienne spożycie folianów (w postaci równoważnika folianów) dla osób dorosłych wynosi $400 \mu \mathrm{g} / \mathrm{d}$, zaś dla kobiet ciężarnych i karmiacych odpowiednio $600 \mu \mathrm{g} / \mathrm{d}$ i $500 \mu \mathrm{g} / \mathrm{d}$. Należy zaznaczyć, iż górny tolerowany poziom spożycia (ang. upper level, UL) dla osób dorosłych wynosi 1 $\mathrm{mg} / \mathrm{d}$, a najniższy poziom narażenia (ang. lowest observed adverse effect level, LOAEL) $5 \mathrm{mg} / \mathrm{d}$ i odnosza się one tylko do syntetycznej formy kwasu foliowego (zawartego w suplementach i fortyfikowanej żywności). Natomiast dawka kwasu foliowego na poziomie $>5 \mathrm{mg} / \mathrm{d}$ zwiazana była $z$ występowaniem objawów neurologicznych. Nie ustalono wartości wskaźnika UL dla folianów naturalnie występującej w żywności (HocH i współaut. 2009, EFSA 2014).

Gdy spożycie kwasu foliowego przekracza zdolność organizmu do jego absorpcji i biotransformacji do aktywnej formy (THF) następuje tworzenie się niezmetabolizowane- go kwasu foliowego (ang. unmetabolised folic acid, UFA) we krwi. Duże dawki UFA moga zwiększać ryzyko wystąienia oraz progresji już obecnego nowotworu na skutek zwiększonej syntezy nukleotydów i replikacji DNA, co prowadzi do intensyfikacji procesu proliferacji oraz wzrostu komórek nowotworowych. Sugeruje się także, iż komórki nowotworowe moga w pozytywny sposób wpływać na ekspresję swoich receptorów folianowych, co pozwala na magazynowanie większej ilości folianów w komórkach i tym samym zwiększenia ich zdolności do podziału (PATEL i SOBCZYŃSKA-MALEFORA 2016). Ponadto, UFA może redukować cytotoksyczność komórek NK i tym samym osłabiać odpowiedź układu odpornościowego przeciw komórkom nowotworowym (PATEL i SOBCZYŃSKA-MALEFORA 2016). Zwiększone spożycie kwasu foliowego najbardziej dodatnio koreluje $z$ wystapieniem raka jelita grubego czy prostaty. Znane jest protekcyjne działanie kwasu foliowego na rozwój cewy nerwowej. Jednak zbyt duże dawki tej witaminy podczas ciąży moga zwiększać ryzyko wystąpienia insulinooporności, cukrzycy typu 2 oraz otyłości u dzieci w wieku 5 lat (KRISHNAVENI i współaut. 2014), a także astmy (SILVA i współaut. 2017). Dodatkowo, nadmierna dawka kwasu foliowego może maskować deficyt witaminy $\mathrm{B}_{12}$, a przez to prowadzić do nieodwracalnych zmian neurologicznych, a także zwiększać ryzyko hipotrofii noworodka (PATEL i SobCZyńsKa-Malefora 2016, SElHub i RoSENBERG 2016). Stwierdzono także, że UFA wykazuje interakcje $z$ lekami przeciwpadaczkowymi, zmniejszając stężenie karbamazepiny, fenobarbitalu oraz fenytoiny, i tym samym zwiększając ryzyko napadu drgawkowego (PATEL i SOBCZYŃSKA-MALEFORA 2016).

Obecnie brak jest specjalnych rekomendacji dotyczacych poziomu spożycia kwasu foliowego w przypadku wzmożonej aktywności fizycznej. Nie istnieje także idealna metoda na oznaczenie całkowitej zawartości folianów w organizmie, jednak uważa się, iż ocenę ich zawartości w osoczu oraz w erytrocytach można uznać za wystarczajacy wskaźnik. Za wartości prawidłowe, świadczące o odpowiednim odżywieniu, należy przyjąć 6-20 ng/ml w surowicy oraz 160-640 ng/ml w erytrocytach. Parametry o niższej wartości (odpowiednio $<3 \mathrm{ng} / \mathrm{ml}$ oraz $<140 \mathrm{ng} / \mathrm{ml}$ ) świadcza o niedoborze (CzECZOT 2008, WHO 2012, EFsA 2014). Warto zaznaczyć, iż zawartość folianów w surowicy odnosi się do ich aktualnego spożycia, natomiast w erytrocytach, do ogólnoustrojowych zapasów $z$ ostatnich 120 dni. Okres wyczerpania magazynów ustrojowych wynosi ok 3-4 miesięcy (CZECZOT 2008, CZYŻEWSKA-MAJCHRZAK 
i PARADOWSKA 2010, WHO 2012, MOUSSA i współaut. 2016).

\section{FOLIANY, KWAS FOLIOWY A WYSIEEK FIZYCZNY}

Foliany $\mathrm{i}$ witamina $\mathrm{B}_{12}$ sa niezbędnymi komponentami w procesie syntezy nowych komórek, w szczególności erytrocytów (erytropoeza), a także naprawy uszkodzonych tkanek (WOOLF i MANORE 2006, CASTELL i współaut. 2009, RODRIGUEZ i DiMARCO 2009, KIM i współaut. 2016). Sama witamina $B_{9}$ zwiazana jest także $\mathrm{z}$ synteza puryn i pirymidyn, a tym samym DNA oraz metabolizmem aminokwasów. Powyższe właściwości moga powodować zwiększenie zapotrzebowania na foliany u osób aktywnych fizycznie, ze względu na konieczność naprawy przez organizm uszkodzonej podczas wysiłku fizycznego tkanki mięśniowej. Dlatego $z$ uwagi na swoja rolę foliany stanowia ważny związek dla sportowców (WOOLF i MANORE 2006).

W przypadku występowania niedoboru witaminy $\mathrm{B}_{9}$ zdolność organizmu do wytwarzania czerwonych krwinek ulega upośledzeniu i może ostatecznie doprowadzić do niedokrwistości megaloblastycznej $\mathrm{z}$ powodu zahamowania przekształcenia megaloblastów w funkcjonalne, dojrzałe erytrocyty. Duże czerwone krwinki nie sa w stanie skutecznie i prawidłowo transportować tlenu do komórek, co może skutkować pogorszeniem wyników sportowych (WOOLF i MANORE 2006, CASTELl i współaut. 2009, RodRIGUEz i DiMARCO 2009)

Wiele cząsteczek w formie zmetylowanej (m.in. acetylocholina, kreatyna, DNA) odgrywa bardzo ważna rolę podczas aktywności fizycznej. Zapotrzebowanie metaboliczne indukowane wzmożoną aktywnościa fizyczna może stymulować większy obrót tych składników w organizmie człowieka. Przypuszcza się, że ich regeneracji może towarzyszyć znaczna stymulacja metabolizmu metioniny. Niestety obecnie mało jest informacji dotyczacych wpływu intensywnego wysiłku na poziom folianów we krwi. KIM i współaut. (2016) zaobserwowali zmniejszenie stężenia kwasu foliowego we krwi szczurów, które poddano regularnemu wysiłkowi fizycznemu przez 5 tygodni, w porównaniu do grupy szczurów „nie trenujących”. Sugerowali, iż spadek ten mógł być zwiazany m.in. właśnie $\mathrm{z}$ wykorzystaniem tego zwiazku $\mathrm{w}$ procesach zwiazanych $\mathrm{z}$ metylacja (w tym $\mathrm{w}$ metabolizmie metioniny).

Kwas foliowy wykazuje potencjalne korzyści w odniesieniu do parametrów sercowo-naczyniowych takich jak: czynność śródbłonka, sztywność tętnic, ciśnienie krwi oraz aktywność zakrzepowa, które pośred- nio moga wpływać na zdolność do wysiłku (Hoch i współaut. 2009). Uznaną metoda oceny stanu i funkcji śródbłonka jest pomiar rozszerzalności (ang. flow-mediated dilation, FMD) tętnicy ramiennej. Zauważono, iż młode biegaczki cierpiące na brak miesiaczki zwiąany $z$ uprawianiem sportu charakteryzowały się znaczaco mniejszym FMD, $\mathrm{w}$ porównaniu do zawodniczek miesiączkujacych (HocH i współaut. 2010, ZACH i współaut. 2011). Ponadto, wartość tego czynnika była porównywalna $z$ wartościami u kobiet starszych $z$ zaburzeniami sercowo-naczyniowymi. Kwas foliowy $(10 \mathrm{mg} / \mathrm{d}$ przez 2 tyg.) poprawia zależne od śródbłonka rozszerzenie naczyń u mężczyzn $z$ nadciśnieniem, choroba niedokrwienna serca, zastoinowa niewydolnościa serca, choroba naczyń obwodowych, cukrzyca typu 2 oraz hiperhomocysteinemia (ZACH i współaut. 2011). Wyniki te skłaniaja do przekonania, iż większa podaż witaminy $\mathrm{B}_{9}$ (znacznie większa niż rekomendowana) może działać w sposób protekcyjny na naczynia krwionośne u specyficznej grupy osób. Badania Hoch i współaut. (2009, 2010) wykazały także pozytywny wpływ suplementacji kwasu foliowego $\mathrm{w}$ ilości 10 $\mathrm{mg} / \mathrm{d}$ (przez 4 tygodnie) na FMD tętnicy ramiennej u biegaczek normalnie miesiaczkujących $z$ prawidłowym stężeniem folianów oraz u biegaczek niemiesiączkujacych $\mathrm{w}$ porównaniu do grupy przyjmujacej placebo. Podobne wyniki przy suplementacji kwasu foliowego na poziomie $10 \mathrm{mg} / \mathrm{d}$ przez 4 tygodnie zaobserwowano $u$ profesjonalnych tancerek baletowych $z$ dysfunkcja śródbłonka (HocH i współaut. 2011).

Istnieje kilka mechanizmów wyjaśniajacych skuteczność terapii kwasem foliowym. Uważa się, iż foliany biora udział $\mathrm{w}$ endogennej regeneracji tetrahydrobiopteryny $\left(\mathrm{BH}_{4}\right)$, niezbędnego kofaktora $\mathrm{w}$ mechanizmie produkcji tlenku azotu przez śródbłonkowa syntaze tlenku azotu (eNOS). Dlatego suplementacja tymi związkami może być związana $z$ większym wytwarzaniem NO. Tlenek azotu jest odpowiedzialny za rozszerzenie tętnicy ramiennej (indukowanej przepływem) wyłącznie u ludzi. Ponadto, znany jest wplyw kwasu foliowego na redukcję stężenia homocysteiny, która może być czynnikiem rozwoju zmian miażdżycowych, co może przyczyniać się do poprawy funkcji śródbłonka (CZECZOT 2008, Hoch i współaut. 2010, Moussa i współaut. 2016). Co więcej, wyniki badań in vitro sugeruja bezpośredni antyoksydacyjny wpływ witaminy $B_{9}$ na układ naczyń krwionośnych, zwiększając biodostępność NO i tym samym poprawiajac FMD (HocH i współaut. 2011, ZACH i współaut. 2011).

Wykazano również związek folianów z funkcjonowaniem tkanki kostnej. W bada- 
niach CARMEL i współaut. (1988) oraz MIELGO-AYUSO i współaut. (2017) stwierdzono, iż niskie stężenie kobalaminy (witaminy $\mathrm{B}_{12}$ ), fosforanu pirydoksalu (witaminy $\mathrm{B}_{6}$ ) oraz folianów w osoczu zwiazane jest ze stymulacja aktywności osteoklastów.

\section{NIEDOBÓR FOLIANÓW U SPORTOWCOW}

Wyniki publikowanych badań oceniających spożycie oraz zaopatrzenie organizmu w foliany wskazuja, że sportowcy moga być również narażeni na ich niedobór. Do głównych przyczyn deficytu witaminy $B_{9}$ należą: niedostateczna podaż w diecie, zwiększone zapotrzebowanie zwiazane $z$ aktywnościa fizyczna, zaburzenia jej wchłaniania w przewodzie pokarmowym oraz stosowanie niektórych leków (np. antykoncepcyjnych). Badania metoda ankietowa $z$ udziałem osób aktywnych fizycznie przed 1989 r. wskazywały, że racja pokarmowa znacznego odsetka kobiet oraz nastolatków trenujacych taniec baletowy czy gimnastykę charakteryzował się udziałem folianów na poziomie mniejszym niż 2/3 ówczesnego zalecanego dziennego spożycia RDA dla kobiet w Stanach Zjednoczonych $(180 \mu \mathrm{g} / \mathrm{d}) \quad$ (LUKASKI 2004). Najnowsze badania wskazuja jednak na znacznie większa podaż kwasu foliowego $z$ dietą wśród atletek, co może być skutkiem wzbogacania produktów spożywczych właśnie w ten kwas (WoOLF i współaut. 2017). Wiedza dotyczaca znaczenia suplementacji ciagle się zmienia i rozwija, co przekłada się na większą świadomość osób aktywnych fizycznie oraz większy odsetek osób stosujących suplementację. Udział procentowy kobiet aktywnych fizycznie $z$ niedoborem folianów (niesuplementujacych) zmniejszył się $z$ 33\% (w 1987r.) do nawet 4\% (już w 1998r.) (Woolf i współaut. 2017). Badania przeprowadzone przez WIERNIUK i WŁODARKA (2013), a także SzCZEPAŃSKA i współaut. (2011) również wykazały, iż dieta osób aktywnych fizycznie (w tym przypadku odpowiednio: młodych mężczyzn uprawiajacych sporty aerobowe oraz młodych dziewczat $z$ gimnazjum sportowego w Warszawie) może być niedoborowa pod względem wartości energetycznej, udziału węglowodanów, białka oraz witamin i składników mineralnych, w tym również folianów (aż ok. 84\% badanych spożywało mniej witaminy $B_{0}$ niż ilości zalecane). HABTE i współaut. (2015) zauważyli, iż u ok. 20\% zbadanych zawodowych biegaczy pochodzenia etiopskiego stężenie folianów we krwi było na poziomie $<5,9 \mathrm{ng} / \mathrm{ml}$, co świadczyło o umiarkowanym deficycie.

Największe ryzyko wystapienia niedoboru obserwuje się u młodych dziewcząt oraz sportowców uprawiających konkurencje $Z$ kategoriami wagowymi lub zwiazanymi $z$ estetyka (m.in. gimnastycy, tancerze baletowi, długodystansowi biegacze, zapaśnicy) $z$ powodu znaczacych restrykcji żywieniowych. To właśnie u takiej specyficznej grupy zawodników interwencje żywieniowe oraz suplementacja kwasem foliowym moga przynieść pozytywne efekty (LUKASKI 2004).

\section{PODSUMOWANIE}

Mając na uwadze wielokierunkowe biologiczne działanie folianów, ich potencjalny wpływ na zdolność do wysiłku oraz ryzyko niedoboru, ocena ich spożycia oraz oznaczanie stężenia we krwi powinny być cyklicznie wykonywane w ramach monitoringu medycznego i dietetycznego sportowców. U osób $z$ ujawnionym niedoborem należy wdrożyć indywidualnie zaplanowana suplementację. Równolegle zaleca się wprowadzenie edukacji żywieniowej mającej na celu zwiększenie spożycia folianów $z$ dietą. Powyższe zabiegi nabieraja szczególnego znaczenia w przypadku młodych sportowców, dopiero nabywających i kształtujacych swoje nawyki żywieniowe, które moga w przyszłości przełożyć się na wyniki sportowe oraz karierę w danym obszarze. Potrzeba większej ilości badań w celu określenia optymalnych dawek ewentualnej suplementacji kwasu foliowego dla sportowców w celu leczenia i profilaktyki niedoboru.

$$
\text { Streszczenie }
$$

Wraz $z$ rozwojem wiedzy $z$ zakresu żywienia człowieka, odpowiedni sposób żywienia (oraz prawidłowy stan odżywienia) osób aktywnych fizycznie nabiera coraz większego znaczenia w kontekście wpływu na ich zdolność do wysiłku. Prawidłowe żywienie ma za zadanie dostarczyć energię i składniki odżywcze na poziomie adekwatnym do zapotrzebowania sportowców. Negatywny wpływ ograniczonego spożycia białka, tłuszczu, węglowodanów na sprawność fizyczna jest dobrze poznany. Inna sytuacja ma miejsce w przypadku niedoboru w diecie witamin i składników mineralnych oraz ich wpływu na zdolność wysiłkową człowieka. Celem pracy było zwrócenie uwagi na rolę folianów w organizmie człowieka, ich wpływu na parametry szczególnie ważne dla sportowców oraz na problem występowania ich niedoborów u osób aktywnych fizycznie. Foliany ( $\mathrm{z}$ witamina $\mathrm{B}_{12}$ ) uczestnicza w kluczowych procesach adaptacyjnych do wysiłku fizycznego, w tym: w podziałach komórek, syntezie i wzroście nowych komórek, biosyntezie zasad purynowych i pirymidynowych, czy naprawie uszkodzonych tkanek. Niestety często odpowiednia podaż folianów nie jest uwzględniana w planach żywieniowych, co prowadzi do występowania ich niedoborów.

\section{LITERATURA}

CARMel R., LAU K. W., Baylink D. J. i współaut., 1988. Cobalamin and osteoblast-specific proteins. N. Engl. J. Med. 319, 70-75. 
Castell L. M., Burke L. M., STEAR S. J., 2009. A-Z of supplements: Dietary supplements, sports nutrition foods and ergogenic aids for health and performance Part 2. Br. J. Sports Med. 43, 807-810.

CIEŚliK E., KośCIEJ A., 2011. Kwas foliowy - wy stepowanie $i$ znaczenie. Probl. Hig. Epidemiol. $93,1-7$

CzECZOT H., 2008. Kwas foliowy $w$ fizjologii $i$ patologii. Post. Hig. 62, 405-419.

CZYŻEWSKA-MAJCHRZAK Ł., PARADOWSKA P., 2010. Skutki niedoboru i ryzyko suplementacji folianów $w$ diecie. Now. Lek. 79, 457-463.

EFSA (European Food Safety Authority Panel On Dietetic Products, Nutrition And Allergies), 2014. Scientific Opinion on Dietary Reference Values for folate. EFSA J. 12, 1-60.

ESKICI G., ERSOY G., 2012. An evaluation of Wheelchair Basketball players' nutritional status and nutritional knowledge levels. J. Sports Med. Phys. Fitness 147, 135-140.

GUJSKA E., MiCHALAK J., CZARNOWSKA M., 2013. Wplyw czasu $i$ temperatury przechowywania na stabilność kwasu foliowego $i$ folianów $w$ wybranych sokach owocowych $i$ owocowo-warzywnych. Żywn. Nauk Technol. Jakość 20, $130-138$.

HABTE K., ADISH A., ZERFU D. i współaut., 2015. Iron, folate and vitamin B12 status of Ethiopian professional runners. Nutr. Metab. 12, $1-10$.

Hoch A. Z., Pajewski N. M., Hoffmann R. G., i współaut., 2009. Possible relationship of folic acid supplementation and improved flow-mediated dilation in premenopausal, eumenorrheic athletic women. J. Sports Sci. Med. 8, 123 129.

HOCH A., LYNCH S., JURVA J. i współaut., 2010. Folic acid supplementation improves vascular function in amenorrheic runners. Clin. J. Sport Med. 20, 205-219.

Hoch A. Z., PAPANEK P., SzaBo A. i współaut., 2011. Folic acid supplementation improves vascular function in professional dancers with endothelial dysfunction. Phys. Med. Rehab. 3, 1005-1012.

JAROSZ M., 2017. Normy żywienia dla populacji Polski. Instytut Żywności i Żywienia, Warszawa.

KALEMBA-DROŻDŻ M., 2011. Niedobory folianów $w$ diecie $i$ ich wpływ na stabilność genetyczna. [W:] Interdyscyplinarne aspekty nauk o zdro wiu. DEBSKA G., JAŚKIEWICZ J. (red.). Oficyna Wydawnicza AFM, Kraków, 21-31.

KIM Y. N., HWANG J. H., CHO Y. O., 2016. The effects of exercise training and acute exercise duration on plasma folate and vitamin B12. Nutr. Res. Pract. 10, 161-166.

KRISHNAVENI G., VEEnA S., KARAT S. i współaut., 2014. Association between maternal folate concentrations during pregnancy and insulin resistance in Indian children. Diabetologia 57, 110-121.

KunACHOWICZ H., PRZYGODA B., NADOLNA I. współaut., 2017. Tabele składu $i$ wartości odżywczej żywności. Wydawnictwo Lekarskie PZWL, Warszawa.

LaskowsKa-Klita T., CheŁchowska M., AmbroszKIEWICZ J. i współaut., 2012. Kwas foliowy - rola $w$ metabolizmie komórki. Bromatol. Chem. Toksykol. 45, 144-151.

LAZOVIĆ M., MilenKović J., BOJANIĆ N. i współaut., 2018. Pathophysiological aspects of oligoelement supplementation in athletes. Acta Med. Medianae 57, 45-52.
LUKASKI H. C., 2004. Vitamin and mineral status: Effects on physical performance. Nutrition 20, 632-644.

MAHMOOD L., 2014. The metabolic processes of folic acid and Vitamin B12 deficiency. J. Health Res. Rev. 1, 5-9.

MARTINEZ S., PASQUARELli B., ROMAGUERA D. I współaut., 2011. Anthropometric characteristics and nutritional profile of young amateur swimmers. J. Strength Cond. Res. 25, 11261133.

MAUghan R. J., BuRKe L. M., DVORAK J. i współaut., 2018. IOC consensus statement: dietary supplements and the high-performance athlete. Br. J. Sports Med. 52, 439-455.

Mielgo-AyUso J., VAltueÑa J., Huybrechts I. i współaut., 2017. Fruit and vegetables consumption is associated with higher vitamin intake and blood vitamin status among European adolescents. Eur. J. Clin. Nutr. 71, 458-467.

Moussa H. N., Hosseini NASAB S., Haidar Z. A. i współaut., 2016. Folic acid supplementation: what is new? Fetal, obstetric, long-term benefits and risks. Fut. Sci. OA 2, 1-11.

PATEL K., SOBCZYŃSKA-MALEFORA A., 2016. The adverse effects of an excessive folic acid in take. Eur. J. Clin. Nutr. 71, 159-163.

Rodriguez N., DiMARCO N., 2009. Position of the American Dietetic Association, Dietitians of Canada, and the American College of Sports Medicine: nutrition and athletic performance. J. Am. Diet. Assoc. 109, 509-527.

Rousseau A. S., Robin S., Roussel A. M. i wspólaut., 2005. Plasma homocysteine is related to folate intake but not training status. Nutr. Metab. Cardiovasc. Dis. 15, 125-133.

SelHub J., RosenberG I. H., 2016. Excessive folic acid intake and relation to adverse health out come. Biochimie 126, 71-78.

SiKORSKA-ZIMNY K., 2013. Wystepowanie oraz wpływ kwasu foliowego na organizm ludzki. Bromatol. Chem. Toksykol. 46, 496-501.

Silva C., KeATing E., PinTO E., 2017. The impact of folic acid supplementation on gestational and long term health: Critical temporal windows, benefits and risks. Porto Biomed. J. 1, $1-18$.

Smith A. D., Kim Y.-I., Refsum H., 2008. Is folic acid good for everyone? Am. J. Clin. Nutr. 87, 517-533.

SZCZEPAŃSKA B., MALCZEWSKA-LENCZOWSKA J., WAJSZCZYK B., 2011. Ocena spożycia witamin $i$ składników mineralnych przez dziewczęta $z$ warszawskiego gimnazjum sportowego. Probl. Hig. Epidemiol. 92, 644-647.

THALER C. J., 2014. Folate metabolism and human reproduction. Geburtshilfe Frauenheilkd $74,845-851$.

Thomas D. T., ERDMAN K. A., BuRKe L. M., 2016. Position of the Academy of Nutrition and Dietetics, Dietitians of Canada, and the American College of Sports Medicine: nutrition and athletic performance. J. Acad. Nutr. Diet. 116, 501-528.

VIJAYAKUMAR A., KIM E., KIM H. i współaut., 2017. Effects of folic acid supplementation on serum homocysteine levels, lipid profiles, and vascular parameters in post-menopausal Korean women with type 2 diabetes mellitus. Nutr. Res. Pract. 11, 327-333.

WHO, 2012. Serum and red blood cell folate con centrations for assessing folate status in populations. Vitamin and Mineral Nutrition Information System. World Health Organization, Geneva. 
WIERNIUK A., WŁODAREK D., 2013. Estimation of energy and nutritional intake of young men practicing aerobic sports. Rocz. Panstw. Zakl. Hig. 64, 143-148.

WinkelS R. M., BROUWER I. A., Siebelink E. i współaut., 2007. Bioavailability of food folates is $80 \%$ of that of folic acid. Am. J. Clin. Nutr. 85, 465-473.

WOOLF K., MANORE M., 2006. B - vitamins and exercise: does exercise alter requirements? Int. J. Sport Nutr. Exerc. Metab. 16, 453-484.
WoOlF K., HaHn N. L., Christensen M. M. i współaut., 2017. Nutrition assessment of B-vitamins in highly active and sedentary women. Nutrients 9, 1-17.

ZACH K. N., SMith MACHIN A. L., Hoch A. Z., 2011. Advances in management of the female athlete triad and eating disorders. Clin. Sports Med. 30, 551-573.

KOSMOS Vol. 68, 2, 249-257, 2019

\section{ALEKSANDRA KARCZEMNA ${ }^{1}$, JAROStaW KRZYWAŃSKI ${ }^{2}$, EWA LANGE ${ }^{1}$}

${ }^{1}$ Department of Dietetics, Faculty of Human Nutrition and Consumer Sciences, Warsaw University of Life Sciences - SGGW, 159C Nowoursynowska Str., 02-776 Warszawa, ${ }^{2}$ National Centre for Sports Medicine, 63A Żwirki $i$ Wigury Str., 02-091 Warszawa, e-mail: aleksandra.karczemna@gmail.com

\section{THE IMPORTANCE OF FOLATES FOR ATHLETES}

\section{Summary}

Along with the development of knowledge in the field of human nutrition, an appropriate diet (and the proper nutritional status) of physically active people is becoming more and more important in the context of the impact on the athlete's performance. Proper nutrition's task is to provide energy and nutrients at a level adequate to the needs of athletes. Adverse effects of limited intake of proteins, fat and carbohydrates for physical fitness are well known. The opposite situation occurs in the case of a deficiency of dietary vitamins and minerals, and their impact on the exercise efficiency. The aim of this work was to draw attention to the role of folates in the human body, their impact on parameters particularly important for athletes and to the problem of their deficiencies in physically active people. Folates (along with compounds such as vitamin $\mathrm{B}_{12}$ ) participate in the key adaptation processes for athletes, including cell division, synthesis and growth of new cells, biosynthesis of purine and pyrimidine bases, and repair of the damaged tissues. Unfortunately, very often adequate supply of folic acid is not included in the nutrition plans, which leads to the occurrence of its shortages.

Key words: folic acid, folate, bioavailability, athletes, physical activity 